\author{
Abstracta Iranica \\ Abstracta Iranica Revue bibliographique pour le domaine irano-aryen \\ Volume 32-33 | 2013 \\ Comptes rendus des publications de 2009-2010
}

\title{
Tomoko Yamagishi. Unaji wo megru seiji tairitsu
}

\section{Yoko Suzuki}

\section{(2) OpenEdition}

\section{Journals}

Édition électronique

URL : http://journals.openedition.org/abstractairanica/41082

DOI : 10.4000/abstractairanica.41082

ISSN : 1961-960X

Éditeur :

CNRS (UMR 7528 Mondes iraniens et indiens), Éditions de l'IFRI

Édition imprimée

Date de publication : 1 décembre 2013

ISSN : 0240-8910

\section{Référence électronique}

Yoko Suzuki, «Tomoko Yamagishi. Unaji wo megru seiji tairitsu », Abstracta Iranica [En ligne], Volume 32-33 | 2013, document 467, mis en ligne le 01 juillet 2016, consulté le 03 octobre 2020. URL : http:// journals.openedition.org/abstractairanica/41082 ; DOI : https://doi.org/10.4000/abstractairanica. 41082

Ce document a été généré automatiquement le 3 octobre 2020.

Tous droits réservés 


\title{
Tomoko Yamagishi. Unaji wo megru seiji tairitsu
}

\author{
Yoko Suzuki
}

\section{RÉFÉRENCE}

Tomoko Yamagishi. « Unaji wo megru seiji tairitsu ». Supotsu kagaku kenkyu, vol. 18, no. 2, 2010, p. 53-66.

[Les conflits politiques en raison de la nuque couverte ou non]

1 Cet article fait partie des études de l'A. sur le féminisme dans l'islam. Cette historienne japonaise de la société iranienne contemporaine examine, ici, l'histoire des sports féminins en Iran, leur progression dans les mouvements islamiques à partir des années 1980 et le développement du foot féminin d'Iran avec ses problèmes vestimentaires. L'article est court et concis. Cependant sa conclusion qui met en question la réconciliation entre la FIFA (Fédération internationale de Football Association) et les autorités iraniennes sur la forme de bonnet des footballeuses qui engage incite une réflexion fine : en effet, alors que les deux parties étaient implicitement d'accord sur l'apparence symbolique de l'islam - la nuque couverte -, la FIFA n'a pas accepté un bonnet qui cache la nuque; les autorités iraniennes ont donc refusé un bonnet laissant la nuque découverte. Elles ont finalement opté pour un bonnet de grande taille, qui satisfaisait les deux parties, car le style était admissible pour l'une, tandis que l'invisibilité du cou a assuré l'autre. Pour dire proprement, elles étaient dans la même logique - que la nuque soit couvert ou non-pour défendre politiquement leur idéologie en trouvant une solution hypocrite. 


\section{AUTEURS}

YOKO SUZUKI

Paris 